\title{
An assessment of residents' and fellows' personal finance literacy: an unmet medical education need
}

\author{
Fahd A. Ahmad1', Andrew J. White'1, Katherine M. Hiller ${ }^{2}$, Richard Amini², Donna B. Jeffe ${ }^{1}$ \\ ${ }^{1}$ Washington University School of Medicine, St. Louis, Missouri, USA \\ ${ }^{2}$ University of Arizona College of Medicine, Tucson, Arizona, USA \\ Correspondence: Fahd A. Ahmad, Department of Pediatrics, Division of Emergency Medicine, Washington University School of \\ Medicine in St. Louis, USA. E-mail: fahd.ahmad@wustl.edu \\ Accepted: April 04, 2017
}

\begin{abstract}
Objectives: This study aimed to assess residents' and fellows' knowledge of finance principles that may affect their personal financial health.

Methods: A cross-sectional, anonymous, web-based survey was administered to a convenience sample of residents and fellows at two academic medical centers. Respondents answered 20 questions on personal finance and 28 questions about their own financial planning, attitudes, and debt. Questions regarding satisfaction with one's financial condition and investment-risk tolerance used a 10-point Likert scale ( 1 =lowest, 10=highest). Of 2,010 trainees, 422 $(21 \%)$ responded (median age 30 years; interquartile range, 28-33).
\end{abstract}

Results: The mean quiz score was $52.0 \%(\mathrm{SD}=19.1)$. Of 299 (71\%) respondents with student loan debt, 144 (48\%) owed over $\$ 200,000$. Many respondents had other debt, including 86 (21\%) with credit card debt. Of 262 respondents with retirement savings, 142 (52\%) had saved less than
$\$ 25,000$. Respondents' mean satisfaction with their current personal financial condition was $4.8(\mathrm{SD}=2.5)$ and investment-risk tolerance was $5.3(\mathrm{SD}=2.3)$. Indebted trainees reported lower satisfaction than trainees without debt (4.4 vs. $\left.6.2, \mathrm{~F}_{(1,419)}=41.57, \mathrm{p}<.001\right)$. Knowledge was moderately correlated with investment-risk tolerance $(\mathrm{r}=0.41, \mathrm{p}<$ .001 ), and weakly correlated with satisfaction with financial status $(\mathrm{r}=0.23, \mathrm{p}<.001)$.

Conclusions: Residents and fellows had low financial literacy and investment-risk tolerance, high debt, and deficits in their financial preparedness. Adding personal financial education to the medical education curriculum would benefit trainees. Providing education in areas such as budgeting, estate planning, investment strategies, and retirement planning early in training can offer significant long-term benefits.

Keywords: Personal finance, graduate medical education, financial literacy, debt

\section{Introduction}

Physicians in the United States earn high salaries after training however they enter the workforce several years after and with greater debt than peers with other professional graduate degrees. The median debt of US medical school graduates is higher than any other post-graduate training population, ${ }^{1}$ with $82 \%$ of recent graduates carrying over $\$ 100,000$ in medical student loans. ${ }^{2,3}$ Trainees who choose fellowship training after residency extend their time working at lower income levels while increasing their debt burden. ${ }^{4}$ Fewer physicians in the US are choosing selfemployment after training, ${ }^{5}$ and these physicians may not perceive a need for learning basic finance or business principles, jeopardizing their future financial health. Financial literacy is not a requirement to be a competent physi- cian, but can significantly impact job satisfaction and productivity. ${ }^{6}$ In most other countries, physicians are among the most well-educated and well-compensated professionals, even though their future incomes and levels of commensurate debt may be lower compared to physicians in the US. Yet, even in countries with different physician reimbursement systems, educating medical trainees regarding budgeting, savings, and financial planning could provide significant long-term benefits for individuals and their medical practice. Despite this, few studies have evaluated the financial literacy of medical trainees, or evaluated the efficacy of interventions to improve financial literacy and changes in behavior. The primary objective of this study was to conduct a needs assessment of residents' and 
fellows' financial literacy (knowledge of personal-finance principles) and their financial status. This information can be used to design educational interventions that focus on improving medical trainees' financial literacy.

\section{Methods}

\section{Study design}

A cross-sectional anonymous survey was administered to a convenience sample of residents and fellows at two US academic medical centers: Washington University School of Medicine in St. Louis and University of Arizona College of Medicine.

\section{Study participants}

The Institutional Review Boards at both institutions approved this study as minimal risk and exempt from ongoing review. All residents and fellows at each study site were invited to participate in the survey via email with a link to the online survey sent through the graduate medical education office at each institution and from residency/fellowship program directors. All responses were anonymous. Three follow-up reminders were sent, and responses were collected from January-March 2015 at Washington University and from June-August 2015 at University of Arizona College of Medicine. The survey was programmed and the data collected using the online Research Electronic Data Capture (REDCap) software. Respondents were eligible to win one of 40 \$25 Amazon.com gift cards from Washington University or 25 gift cards at University of Arizona. Respondents' contact information for the lottery was not linked to survey responses.

Recruitment emails were sent to 1,114 trainees at Washington University and 896 trainees at University of Arizona College of Medicine. The graduate medical education office at Washington University sent invitation emails to all trainees, while individual program directors at the University of Arizona sent the email invitations to their trainees. Some trainees at the University of Arizona started after or completed training during their enrollment period and might not have received all email invitations/reminders. Nevertheless, all trainees were included when determining the response rate as we could not verify which trainees received which emails. At Washington University, there were 289 responses (26\%), and at University of Arizona, there were 133 responses (15\%), for a total of 422 responses (21\%).

Table 1 provides characteristics of respondents by institution. Respondents from the two sites were similar with regard to age, marital status, dependent children, and parental education levels. A higher percentage of respondents from Washington University indicated their future work plans would be in an academic or university environment.
Table 1. Characteristics of resident and fellow participants $(\mathrm{N}=422)$

\begin{tabular}{|c|c|c|c|}
\hline Demographics & $\begin{array}{l}\text { Washington } \\
\text { University } \\
(n=289)\end{array}$ & $\begin{array}{l}\text { University } \\
\text { of Arizona } \\
(n=133)\end{array}$ & $\begin{array}{c}\text { Total } \\
(\mathrm{N}=422)\end{array}$ \\
\hline $\begin{array}{l}\text { Age in years, median (interquartile } \\
\text { range, IQR) }\end{array}$ & $30(28-33)$ & $30(28-33)$ & $30(28-33)$ \\
\hline $\begin{array}{l}\text { Post-graduate year level, median } \\
\text { (IQR) }\end{array}$ & $3(2-5)$ & $2(1-4)$ & $3(2-4)$ \\
\hline \multicolumn{4}{|l|}{ Current Marital Status, n (\%) } \\
\hline Married/Partner & $174(60.2)$ & $74(55.6)$ & $248(58.8)$ \\
\hline Single & $108(37.4)$ & $54(40.6)$ & $162(38.4)$ \\
\hline Separated & $1(0.3)$ & 0 & $1(0.2)$ \\
\hline Divorced & $2(0.7)$ & $1(0.8)$ & $3(0.7)$ \\
\hline Did not answer & $4(1.4)$ & $4(3.0)$ & $8(1.9)$ \\
\hline \multicolumn{4}{|l|}{ Have dependent children, $\mathrm{n}(\%)$} \\
\hline Yes & $89(30.8)$ & $33(24.8)$ & $122(28.9)$ \\
\hline No & $200(69.2)$ & $100(75.2)$ & $300(71.1)$ \\
\hline \multicolumn{4}{|l|}{ Highest maternal education, n (\%) } \\
\hline $\begin{array}{l}\text { Some high school or high } \\
\text { school graduate }\end{array}$ & $29(10.0)$ & $9(6.8)$ & $38(9.0)$ \\
\hline $\begin{array}{l}\text { Specialized business/technical } \\
\text { training }\end{array}$ & $4(1.4)$ & $4(3.0)$ & $8(1.9)$ \\
\hline $\begin{array}{l}\text { Some college or college de- } \\
\text { gree }\end{array}$ & $114(39.4)$ & $66(49.6)$ & $180(42.7)$ \\
\hline $\begin{array}{l}\text { Some graduate school or } \\
\text { graduate degree(s) }\end{array}$ & $137(47.4)$ & $51(38.3)$ & $188(44.5)$ \\
\hline Did not answer & $5(1.7)$ & $3(2.3)$ & $8(1.9)$ \\
\hline \multicolumn{4}{|l|}{ Highest paternal education } \\
\hline $\begin{array}{l}\text { Some high school or high } \\
\text { school graduate }\end{array}$ & $21(7.3)$ & $9(6.8)$ & $30(7.1)$ \\
\hline $\begin{array}{l}\text { Specialized business/technical } \\
\text { training }\end{array}$ & $3(1.0)$ & $5(3.8)$ & $8(1.9)$ \\
\hline $\begin{array}{l}\text { Some college or college } \\
\text { degree }\end{array}$ & $83(28.7)$ & $43(32.4)$ & $126(29.9)$ \\
\hline $\begin{array}{l}\text { Some graduate school or } \\
\text { graduate degree(s) }\end{array}$ & $177(61.2)$ & $72(54.1)$ & $249(59.0)$ \\
\hline Did not answer & $5(1.7)$ & $4(3.0)$ & $9(2.1)$ \\
\hline \multicolumn{4}{|l|}{ Future work plans } \\
\hline Academic/university & $121(41.9)$ & $31(23.3)$ & $152(36.0)$ \\
\hline Private & $70(24.2)$ & $41(30.8)$ & $111(26.3)$ \\
\hline Uncertain & 95 (32.9) & 57 (42.9) & $152(36.0)$ \\
\hline Other & $3(1.0)$ & $3(2.3)$ & $6(1.4)$ \\
\hline Did not answer & 0 & $1(0.8)$ & $1(0.2)$ \\
\hline \multicolumn{4}{|l|}{ Specialty } \\
\hline Internal Medicine & $62(21.5)$ & 35 (26.3) & $97(23.0)$ \\
\hline Pediatrics & $61(21.1)$ & $17(12.8)$ & $78(18.5)$ \\
\hline Emergency Medicine & $18(6.2)$ & $21(15.8)$ & $39(9.2)$ \\
\hline Radiology & $25(8.7)$ & $12(9.0)$ & $37(8.8)$ \\
\hline Surgery & $28(9.7)$ & $6(4.5)$ & $34(8.1)$ \\
\hline Anesthesiology & $27(9.3)$ & $2(1.5)$ & $29(6.9)$ \\
\hline Psychiatry & $12(4.2)$ & $11(8.3)$ & $23(5.5)$ \\
\hline Pathology & $9(3.1)$ & $9(6.8)$ & $18(4.3)$ \\
\hline Other & $43(14.9)$ & $13(9.8)$ & $56(13.3)$ \\
\hline Did not answer & $4(1.4)$ & $7(5.3)$ & $11(2.6)$ \\
\hline
\end{tabular}

\section{Data collection}

A 48-item questionnaire on personal finance and investment knowledge was derived largely from existing national surveys from the Financial Industry Regulatory Authority (FINRA), with their permission.-10 FINRA is an independent, not-for-profit organization, authorized by the US government to create and enforce rules governing financial brokers that create protections for individual investors. As part of this mission, they periodically assess the financial knowledge of US citizens. FINRA created these survey instruments in conjunction with experts in finance and business, including members of the Employee Benefit 
Research Institute and the American Institute of Certified Public Accountants. Survey questions were piloted by FINRA using multiple in-person interviews, then they were further modified after obtaining feedback from delivering the questions using Computer Aided Telephone Interviews. After reviewing FINRA questionnaires ourselves, we consulted a physician expert in personal finance to provide additional review of the FINRA questions and to develop additional questions to answer our study aims. All questions were then reviewed for accuracy and clarity of wording by physicians not on the study team before distribution.

The questionnaire (Appendix) included multiple-choice and open-ended questions in two parts: 1) twenty questions assessing knowledge of basic financial topics regarding savings and investing, and 2) twenty-eight questions assessing attitudes and behaviors about trainees' own personal financial status and planning, investment-risk tolerance, and satisfaction with their financial condition. Questions regarding satisfaction with one's financial condition and investment-risk tolerance used a 10-point Likert scale (1=lowest, 10 =highest).

\section{Statistical analysis}

Responses were included for analysis if respondents provided any answer to more than half of the 20 knowledge questions (including "I don't know") and answered any of the subsequent demographic questions. When calculating the proportion of correct responses to the knowledge questions, skipped questions and "I don't know" responses were considered incorrect responses.

Chi-square or Fisher's exact tests, as appropriate, were used to measure associations between two categorical variables (e.g., demographics, whether or not respondent had savings, or checked his/her credit report or score). Pearson correlations measured associations among the continuous variables (total knowledge scores, satisfaction with personal financial condition, and investment-risk tolerance), and one-way analyses of variance (ANOVA) measured between-groups differences in these continuous variables. Analyses were performed with IBM SPSS Statistics version 22.0 .

\section{Results}

\section{Quiz scores}

The Appendix provides the individual quiz questions, answer choices, and proportion of respondents answering each question correctly. The mean quiz score (percentage of 20 items answered correctly) was $52 \%$ ( $S D=19.1$; range 0 $100 \%)$. Some questions relating to basic investing principles had a relatively low proportion of correct responses, e.g., that no-load mutual funds carry no sales charges (13\%) and that if interest rates rise, bond prices tend to fall (19.9\%). A greater proportion of respondents with children (76/121 [62.8\%]) than respondents without children (120/300 [40.0\%]) knew that a Section 529 Plan (in the US) is a tax194 advantaged way to provide savings for college ( $\chi 2$ (3, $\mathrm{N}=421)=18.93, \mathrm{p}<.001)$.

\section{Savings, debt, and income}

Table 2 provides information regarding savings, debt, and overall spending. Nearly one-third of respondents indicated some difficulty in meeting monthly expenses. Respondents reported high debt levels, with 332 (79\%) reporting some combination of mortgage, credit card, or student loan debt (Table 2 and Figure 1). One hundred forty-four (48\% of 299) respondents with student loans owed over $\$ 200,000$, and 126 (92\% of 137) of those with a mortgage owed more than $\$ 100,000$. Eighty-six (20\%) respondents had credit card debt that would not be paid off at the end of the month, 27 (32\%) of whom expected to carry more than $\$ 10,000$ to the next month.

Retirement savings were low, with 160 (38\%) respondents reporting no retirement savings, and of 262 respondents with retirement savings, 56\% (142/256) had under $\$ 25,000$ (six participants did not provide savings amount). Respondents who had projected their necessary retirement savings were more likely to have reported having some retirement savings than those who did not (83\% [139/167] vs. $49 \%$ [123/253], $\left.\chi^{2}(1, \mathrm{~N}=420)=51.37, \mathrm{p}<.001\right)$. Respondents with any debt (credit card, mortgage, student loan) had higher mean quiz scores than those without debt (53.1 $[\mathrm{SD}=18.2]$ vs. $48.0[\mathrm{SD}=21.7], \mathrm{F}_{(1,419)}=5.11, \mathrm{p}$ $=0.02$ )

\section{Financial planning}

Table 2 also provides an overview of respondents' financial planning status. One hundred ninety-seven had obtained professional financial advice in the previous five years, with $57.8 \%$ receiving advice for free, and the remainder paying for advice in various ways. Although few respondents had wills, respondents with children were more likely to have a will than those without children (17/121 [14\%] vs. 14/300 [5\%], $\left.\chi^{2}(1, \mathrm{~N}=421)=11.13, \mathrm{p}=.001\right)$. Many respondents had not checked their credit score or report, with 154 (37\%) of all respondents checking neither in the past year.

\section{Satisfaction and investment-risk tolerance}

Respondents' mean willingness to take investment risk was 5.3 (SD = 2.3), with a bell-shaped distribution. Investmentrisk tolerance did not differ significantly between respondents with and without debt (5.2 vs. $5.6, \mathrm{~F}_{(1,418)}=2.19, \mathrm{p}=$ .14). Higher knowledge scores were moderately correlated with greater investment-risk tolerance $(\mathrm{r}=0.408, \mathrm{p}<.001)$.

Respondents' mean satisfaction with their personal financial condition was $4.8(\mathrm{SD}=2.5)$, with nearly all respondents answering between 1-8. Trainees with any debt (student loan, mortgage, or credit card) reported lower satisfaction than trainees without debt (4.4 vs. $6.2, \mathrm{~F}_{(1,419)}=$ $41.57, \mathrm{p}<.001)$. Higher knowledge scores on the quiz were weakly correlated with greater satisfaction of personal financial condition $\left(\mathrm{r}=.226, \mathrm{~F}_{(20,401)}=2.11, \mathrm{p}<.001\right)$. 
Table 2. Financial status and practices of trainees $(\mathrm{N}=422)$

\begin{tabular}{|c|c|}
\hline Survey questions & $\begin{array}{l}\text { Survey } \\
\text { responses } \\
\mathrm{n}(\%)\end{array}$ \\
\hline Financial Planning Status & \\
\hline $\begin{array}{l}\text { Checked credit score in prior } 12 \text { months } \\
\text { Obtained copy of credit report in prior } 12 \text { months } \\
\text { Asked financial professional for advice in past } 5 \text { years } \\
\text { Types of financial advice obtained }\end{array}$ & $\begin{array}{l}243(57.6) \\
218(51.7) \\
197(46.7)\end{array}$ \\
\hline $\begin{array}{l}\text { Debt counselling } \\
\text { Savings or investments } \\
\text { Taking out a loan or mortgage } \\
\text { Insurance of any type } \\
\text { Tax planning } \\
\text { Estate planning } \\
\text { Asset protection }\end{array}$ & $\begin{array}{c}93(47.2) \\
136(69.0) \\
68(34.5) \\
109(55.3) \\
59(30.0) \\
25(12.7) \\
34(17.3)\end{array}$ \\
\hline $\begin{array}{l}\text { How paid for financial advice }{ }^{\dagger} \\
\text { Advice was free } \\
\text { Commission on purchased products } \\
\text { Yearly retainer } \\
\text { Asset under management (AUM) fee } \\
\text { Combination of above } \\
\text { Doesn't know } \\
\text { Attended financial planning seminars at university } \\
\text { Have a will }\end{array}$ & $\begin{aligned} & 114(27.0) \\
& 28(6.6) \\
& 10(2.4) \\
& 10(2.4) \\
& 22(5.2) \\
& 10(2.4) \\
& 129(30.6) \\
& 31(7.3)\end{aligned}$ \\
\hline $\begin{array}{l}\text { Savings } \\
\text { Have an emergency fund for } 3 \text { month's expenses } \\
\text { Can come up with } \$ 2,000 \text { within the next month } \\
\text { Have projected necessary retirement savings } \\
\text { Have retirement savings (any) } \\
\text { Money set aside for children's college education (any) }{ }^{\star \neq}\end{array}$ & $\begin{array}{l}278(65.9) \\
321(76.1) \\
168(39.8) \\
262(62.1) \\
47(38.5)\end{array}$ \\
\hline $\begin{array}{l}\text { Debt } \\
\text { Have a mortgage (any) } \\
\text { Have credit card debt (any) } \\
\text { Have student loans (any) } \\
\text { Have any of the above debt }\end{array}$ & $\begin{array}{l}137(32.5) \\
86(20.4) \\
299(70.9) \\
332(78.7)\end{array}$ \\
\hline Income and expenses & \\
\hline $\begin{array}{l}\text { Difficulty meeting monthly expenses } \\
\text { Very difficult } \\
\text { Somewhat difficult } \\
\text { Not at all difficult }\end{array}$ & $\begin{array}{c}24(5.7) \\
111(26.3) \\
287(68.0)\end{array}$ \\
\hline $\begin{array}{l}\text { Money spent in relation to annual income over prior year } \\
\text { Spent less than income } \\
\text { Spent about the same as income } \\
\text { Spent more than income }\end{array}$ & $\begin{array}{c}283(67.1) \\
89(21.1) \\
50(11.8)\end{array}$ \\
\hline $\begin{array}{l}\text { Confidence in covering an unexpected } \$ 2,000 \text { expense } \\
\text { Certain } \\
\text { Probably } \\
\text { Probably not } \\
\text { Definitely not }\end{array}$ & $\begin{array}{l}321(76.1) \\
71(16.8) \\
19(4.5) \\
11(2.6)\end{array}$ \\
\hline
\end{tabular}

Items with 1 missing response

${ }^{\dagger}$ Among those 197 respondents who obtained professional advice

${ }^{\ddagger}$ Among those 122 respondents with dependent children

\section{Discussion}

We found serious deficits in financial knowledge in a broad range of topics and in financial planning among trainees at two academic medical institutions in the US Trainees reported high debt levels, minimal retirement investments, and having difficulty with cash flow. In addition, trainees reported low levels of satisfaction with their financial status and were largely averse to high-risk investments, which generally have potential for greater yield for future expenses, such as for their children's education or their own retirement. Nearly one-third of respondents reported difficulty meeting their monthly expenses and reported spending all or more of their income each month. Despite having an income similar to the national median income, ${ }^{11}$ and an expectation of a significantly higher future income after training, our study participants were less satisfied with their personal financial condition than the average US citizen. ${ }^{9}$ As educators, we cannot assume that knowledge deficits will be rectified with time; moreover, higher income does not necessarily come with greater financial knowledge. There is increasing recognition that financial literacy offered at the workplace can improve workplace satisfaction and job performance, in addition to improving one's financial health. ${ }^{6,12-15}$ There is every reason to expect that physicians would also benefit from such instruction.

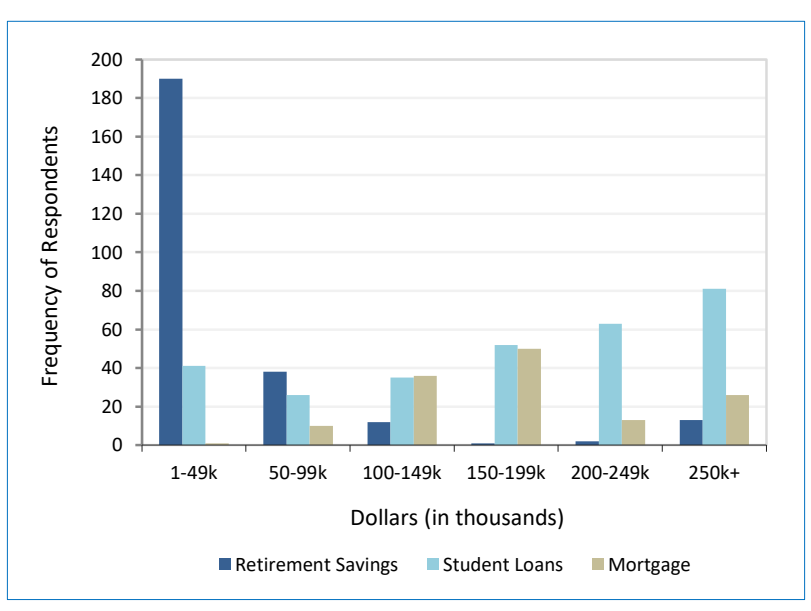

Figure 1. Amount of money in retirement savings, student loan debt, and mortgage debt among trainees who have savings or are indebted $(\mathrm{N}=387)$. Only trainees with any retirement savings $(n=262)$, student loans $(n=299)$, or mortgages $(n=137)$ are represented.

Respondents had similar levels of mortgage debt, substantially higher student loan debt, and lower levels of credit card debt than the average US household. ${ }^{16}$ While lower than the national average, the prevalence of credit card debt was concerning, given the high interest rates, ${ }^{17}$ potential for creating emotional stress, ${ }^{18}$ and already high levels of student loan debt. Reducing or eliminating credit card debt should be a high priority for medical students and graduates, as they face larger student debt burdens than other professional graduates. ${ }^{1}$

Fewer than half of the respondents had projected their necessary retirement savings or obtained professional advice from financial planners during the previous five years. While retirement savings are expected to be low early in post-graduate training, financial planning strategies to minimize additional debt and to build savings should already be in place. Many physicians in training care for seriously ill or dying patients and are taught about advance directives. However, most respondents, including those with children, lacked a will, a basic estate-planning tool. Only half of respondents had reviewed their credit report or credit score in the past year. Checking one's credit report online is free up to three times per year, ${ }^{19}$ and checking one's credit scores is available online without cost. ${ }^{20}$ Maintaining a good credit history is an important part of financial planning.

Trainees also showed low levels of knowledge about health insurance. Few respondents knew that individuals must have a high-deductible health plan in order to make 
contributions to a HSA. Familiarity with different health insurance plans is important for healthcare providers so that they understand the requirements for, and ramifications of, different types of coverage, both personally and professionally for patient care.

As personal finance has been largely neglected by the medical education system, it has created a vacuum that has been filled by a cottage industry of financial advisors who exist solely to provide financial advice to physicians. Many advisors are highly qualified and well-intentioned, however some charge unreasonably high fees for their services, or encourage customers to buy inappropriate products. A recent study found that $20 \%$ of financial advisors have been disciplined for misconduct, ${ }^{21}$ and physicians in training are at high-risk for being the target (and victim) of unscrupulous advisors. Medical educators have the opportunity to help physicians develop a financial knowledge base necessary to understand basic finance and investment principles. With improved financial literacy, physicians in training might better manage their debt and learn more about the benefits and risks of a variety of investment options, improve their current and future financial health, and be empowered to identify qualified and competent financial advisors.

Coursework about the basics of personal financial planning and important financial considerations relevant to medical practice and health insurance should be incorporated into the curriculum during medical school and graduate medical education. Even brief interventions early in training, such as improving the understanding of the risk involved in different types of investments, or diversifying investments in order to minimize risk of loss of capital, could lead to large financial benefits. Student loan debt is already very high for many trainees, and poor financial habits (e.g., misuse of credit cards) may add to their already stressed debt burden. Thus, financial education for medical trainees could show long-term improvements in physicians' financial health, both personally and in practice.

The Accreditation Council for Graduate Medical Education (ACGME) has instituted duty-hour restrictions to reduce fatigue and help trainees perform at high levels during their clinical training. ${ }^{22}$ Financial stress also has the potential to negatively impact work performance during and after training. ${ }^{23,24}$ Educating medical students and trainees to help mitigate this stress should therefore be made an educational priority, and the Association for American Medical Colleges offers some financial planning resources for use. ${ }^{25}$ However, based on our needs assessment, we recommend, at a minimum, that every trainee receive specific instruction in the following aspects of financial education during medical school and residency:

1. How to make a monthly budget

2. Debt/loan management and credit scores/reports

3. Savings and retirement planning options
4. Life, health, and disability insurance

5. Estate planning strategies

Several small, single-site studies have described assessment of financial knowledge or implementation of financial education for healthcare trainees ${ }^{26-31}$ Dhaliwal and colleagues found that a short, 90-minute seminar on personal finance led to a change in the types of investment chosen for medical residents' retirement funds, demonstrating the potential for considerable impact from small interventions. ${ }^{32}$ Financial-literacy interventions in other fields have demonstrated the ability to improve financial decisionmaking and perceived well-being. ${ }^{33}$

Mizell and colleagues described a comprehensive financial-management curriculum for surgery residents at their institution. ${ }^{26}$ The curriculum covered an array of topics, with many lectures integrated into their mandatory Grand Rounds sessions. The development and successful integration of this curriculum into an already demanding general surgery residency program demonstrates the potential for incorporating financial education into any medical or surgical training program. This program benefited directly from the availability of a surgeon who is also a certified financial planner. Whether such a curriculum could be broadly implemented in other training programs remains to be seen.

We observed important deficits in core knowledge about personal finance topics, such as debt management, savings, and estate planning, which can have an immediate and long-term impact on one's financial health. Training on practice management, coding, and billing is also important for physicians, but content might vary across specialties and practice settings. Teaching universal financial literacy skills in the workplace is increasingly common across a variety of industries. With increasing levels of medical school debt, residents and fellows face critical financial challenges, some of which they might not even be aware, as they continue their post-graduate training. Given the potential for negative consequences of financial stress on physicians' emotional well-being and work performance, ${ }^{23,24}$ incorporating basic financial education into the curriculum during medical school and post-graduate training makes good professional sense.

\section{Limitations}

A selection bias due to relatively low response rates and surveying a convenience sample of trainees at only two sites could limit the generalizability of our results. Although we only surveyed two institutions, the sample included a diverse sample of graduates from various medical schools. Moreover, personal finance education was not offered as part of the training curricula at either of these institutions and is not widely offered in medical training programs across the US. Thus, although participants might have been more interested in the topic than non-participants, we 
would not expect that participants differed greatly in terms of their financial knowledge and preparedness compared with non-participants at these two institutions nor with trainees at other training programs. Another limitation is that the two sites enrolled at different times of year, which could have affected participation rates and participants' responses. $^{34}$ As with all self-reported attitudes and behaviors, participants' responses could be subject to recall and self-protection bias.

\section{Conclusions}

The ACGME and medical educators at all levels of training should strive to improve the financial literacy of medical providers through implementation of personal finance, health insurance, and medical-practice-related financial curricula at US medical institutions. Further, these curricular changes should be evaluated for their effectiveness in increasing physicians' financial knowledge and engagement in financial-planning behaviors that could protect their financial security and reduce financial-related stress and its impact of work performance. Future longitudinal studies should also evaluate changes in knowledge and behavior during and after training.

\section{Acknowledgments}

The authors wish to thank James M. Dahle, MD, Department Chair, Utah Emergency Specialists, for his assistance in refining the survey tool, and Lauren Yaeger, MA, MLIS, St. Louis Children's Hospital in partnership with Washington University School of Medicine in St. Louis, for her assistance in the literature search.

\section{Conflict of Interest}

The authors declare that they have no conflict of interest.

\section{References}

1. Woods D. Medicine, law, business: which grad students borrow the most? NPR2015 [cited 21 March 2017]; Available from: http://www. npr.org/sections/money/2015/07/15/422590257/medicine-law- business-which-grad-students-borrow-the-most.

2. Association of American Medical Colleges. Medical student education: debt, costs, and loan repayment fact card. 2016 [cited 21 March 2017]; Available from: https://members.aamc.org/eweb/upload/2016_Debt_ Fact_Card.pdf.

3. American Association of Medical Colleges. Physician education debt and the cost to attend medical school: 2012 Update. 2013 [cited 21 March 2017]; Available from: https://members.aamc.org/eweb/upload/Physician $\% 20$ Education\%20Debt\%20and\%20the\%20Cost\%20to\%20Attend\%20Medica 1\%20School,\%202012\%20Update.pdf.

4. American Board of Internal Medicine. Number of internal medicine fellows by year of training. 2015 [cited 21 March 2017]; Available from: http://www.abim.org/about/statistics-data/resident-fellow-workforce-

data/number-fellows-by-year-of-training.aspx.

5. Flanagan N. More physicians leaving independent practices. 2015 [cited 21 March 2017]; Available from: http://www.healthcaredive.com/news /more-physicians-leaving-independent-practices/403653/.
6. Hira TK, Loibl C. Understanding the impact of employer-provided financial education on workplace satisfaction. Journal of Consumer Affairs. 2005;39(1):173-94.

7. FINRA. National Financial Capability Study. 2014 [cited 21 March 2017]; Available from: http://www.usfinancialcapability.org/quiz.php.

8. FINRA. Investor knowledge quiz; a helpful guide to learning more about investing. 2012 [cited 21 March 2017]; Available from: http://www.finra.org/sites/default/files/InvestorDocument/p014495.pdf.

9. FINRA. Financial capability in the united states; report of fundings from the 2012 National Financial Capability Study. 2013 [cited 21 March 2017]; Available from: http://www.usfinancialcapability.org/downloads /NFCS_2012_Report_Natl_Findings.pdf.

10. FINRA. National financial capability study methodology. 2017 [cited 21 March 2017]; Available from: http://www.usfinancialcapability.org /downloads/NFCS_2009_Natl_Full_Report.pdf.

11. DeNavas-Walt C, Proctor BD, Smith JC. US Census Bureau. Income and poverty in the United States: 2013. Washington, DC: United States Census Bureau; 2014.

12. Prawitz AD, Cohart J. Workplace financial education facilitates improvement in personal financial behaviors. Journal of Financial Counseling and Planning. 2014;25(1).

13. Bannon S, Ford K, Meltzer L. Financial literacy programs in the workplace. The CPA Journal. 2014;84(9):67.

14. Verne J. Financial wellness programs to reduce employee stress. Compensation \& Benefits Review. 2014;46(5-6):304-8.

15. Joo S-h, Grable JE. Employee education and the likelihood of having a retirement savings program. Journal of Financial Counseling and Planning. 2005;16(1).

16. El Issa E. American Household Credit Card Debt Study. Nerdwallet2015 [cited 21 March 2017]; Available from: https://www.nerdwallet.com/blog/credit-card-data/average-credit-carddebt-household/.

17. Campbell J. Rating your debt, from best to worst. Money management international: money management international; 2013 [cited 21 March 2017]; Available from: http://www.moneymanagement.org/Community /Blogs/Blogging-for-Change/2013/March/Rating-your-debt-from-best-toworst.aspx.

18. Hodson R, Dwyer R, Neilson L. Credit card blues: the middle class and the hidden costs of easy credit. Sociol Q. 2014;55(2):315-40.

19. Central Source LLC. 2016 [cited 21 March 2017]; Available from: https://www.annualcreditreport.com/index.action.

20. Carrns A. Free FICO Credit Scores: options grow for consumers. The New York Times; 2015 [cited 21 March 2017]; Available from: https://www.nytimes.com/2015/01/22/your-money/credit-scores/free-ficocredit-scores-options-grow-for-consumers.html?_r=1.

21. Egan M, Matvos G, Seru A. The market for financial adviser misconduct. Social Science Research Network [cited 21 March 2017]; 2016 Available from: http://ssrn.com/abstract=2739170.

22. Accreditation Council for Graduate Medical Education. ACGME Common Program Requirements. 2017 [cited 21 March 2017]; Available from: http://www.acgme.org/What-We-Do/Accreditation/CommonProgram-Requirements.

23. Kim J, Garman ET. Financial stress and absenteeism: an empirically derived research model. Journal of Financial Counseling and Planning. 2003;14(1):31-42.

24. Garman ET, Leech IE, Grable JE. The Negative impact of employee poor personal financial behaviors on employers. Journal of Financial Counseling and Planning. 1996;7:157-68.

25. American Association of Medical Colleges. AAMC Financial Aid. 2016 [cited 21 March 2017]; Available from: https://studentsresidents.aamc.org/financial-aid/.

26. Mizell JS, Berry KS, Kimbrough MK, Bentley FR, Clardy JA, Turnage RH. Money matters: a resident curriculum for financial management. J Surg Res. 2014;192(2):348-55.

27. Liebzeit J, Behler M, Heron S, Santen S. Financial literacy for the graduating medical student. Med Educ. 2011;45(11):1145-6.

28. Wherry JE, Thomalla K. The transition from resident to private practice--important financial decisions. Oral Maxillofac Surg Clin North Am. 2008;20(1):109-18. 
29. Witek M, Siglin J, Malatesta T, Snook A, Gressen E, Rudoler S, et al. Is financial literacy necessary for radiation oncology residents? Int J Radiat Oncol Biol Phys. 2014;90(5):986-7.

30. Chui MA. An elective course in personal finance for health care professionals. Am J Pharm Educ. 2009;73(1):6.

31. Hauge LS, Frischknecht AC, Gauger PG, Hirshfield LE, Harkins D, Butz DA, et al. Web-based curriculum improves residents' knowledge of health care business. J Am Coll Surg. 2010;211(6):777-83.
32. Dhaliwal G, Chou CL. A brief educational intervention in personal finance for medical residents. J Gen Intern Med. 2007;22(3):374-7.

33. Garman ET, Kim J, Kratzer CY, Brunson BH, Joo S-h. Workplace financial education improves personal financial wellness. Journal of Financial Counseling and Planning. 1999;10(1):81-91.

34. Dillman DA, Smyth JD, Christian LM, Dillman DA. Internet, mail, and mixed-mode surveys: the tailored design method. 3rd ed. Hoboken, NJ: Wiley \& Sons; 2009. 


\section{Appendix}

\section{Survey Questions}

$\mathrm{N}=422$

\section{Part 1 - Financial Knowledge Quiz}

Correct response bolded, with \% of sample responding correctly shown for each question

All questions multiple-choice

1. Suppose you have $\$ 100$ in a savings account earning 2 percent interest a year. After five years, how much would you have?

$\begin{array}{ll}\text { o } & \text { More than } \$ 102(\mathbf{9 6 . 4 \% )} \\ \text { o } & \text { Exactly } \$ 102 \\ \text { o } & \text { Less than } \$ 102 \\ \text { o } & \text { I don't know }\end{array}$

2. In general, investments that are riskier tend to provide higher returns over time than investments with less risk.
o True $(64.5 \%)$
o False
o I don't know

3. Buying a single company's stock usually provides a safer return than a stock mutual fund.
o True
o False (87.2\%)
o I don't know

4. Which account allows for tax-free withdrawals in retirement?

$\begin{array}{ll}\text { o } & \text { Traditional IRA } \\ \text { o } & \text { Roth IRA (65.4\%) } \\ \text { o } & 401(\mathrm{k}) \\ \text { o } & 457 \\ \text { o } & \text { I don't know }\end{array}$

5. A 15-year mortgage typically requires higher monthly payments than a 30-year mortgage but the total interest over the life of the loan will be less.
o True $(94.5 \%)$
o False
o I don't know

6. Imagine that the interest rate on your savings account is 1 percent a year and inflation is 2 percent a year. After one year, would the money in the account buy more than it does today, exactly the same or less than today?
o More
o Same
o Less $\mathbf{( 9 0 . 5 \% )}$
o I don't know

7. A "no-load" mutual fund is one that...
o Carries no fees
o Carries no sales charges (13.3\%)
o Does not contain high-risk securities
o Has no limits on the period of time in which it can be bought and sold
o I don't know

8. A Section 529 Plan is a tax-advantaged way to save for:
o College $(46.4 \%)$
o Retirement
o Long-term health care
o I don't know

9. Which of the following is true about Health Savings Accounts:
o You must have a high-deductible health plan in order to make contributions $(\mathbf{1 1 . 8 \% )}$
o You must have a high-deductible health plan in order to make withdrawals
- After age 62, you can spend the money in an HSA on a boat without a penalty
o HSAs provide a tax deduction when you contribute, but provide withdrawals are taxed as ordinary income
o I don't know

10. Which of these two funds has less oversight from government regulators?
o Mutual funds
o Hedge funds $(39.3 \%)$
o They receive the same oversight
o I don't know 
11. Which of the following organizations insures you against your losses in the stock market?

o FDIC (Federal Deposit Insurance Corporation)

o FINRA (Financial Industry Regulatory Authority)

- SEC (Securities and Exchange Commission)

o SIPC (Securities Investor Protection Corporation)

o None of the above $(41.2 \%)$

o I don't know

12. If a company files for bankruptcy, which of the following securities is most at risk of becoming virtually worthless?
o The company's preferred stock
o The company's common stock $\mathbf{( 4 3 . 6 \% )}$
o The company's bonds
o I don't know

13. Which is the best definition of "selling short"?

0 Selling shares of a stock shortly after buying it

o Selling shares of a stock before it has reached its peak

o Selling shares of a stock at a loss

o Selling borrowed shares of a stock $(22.7 \%)$

o I don't know

14. If you buy a company's stock...
o You own a part of the company $(\mathbf{8 1 . 5 \% )}$
o You have lent money to the company
o You are liable for the company's debts
o The company will return your original investment to you with interest
o I don't know

15. If you buy a company's bond...

$\begin{array}{ll}\text { o } & \text { You own a part of the company } \\ \text { o } & \text { You have lent money to the company (71.3\%) } \\ \text { o } & \text { You are liable for the company's debts } \\ \text { o } & \text { You can vote on shareholder resolutions } \\ \text { o } & \text { I don't know }\end{array}$

16. If interest rates rise, what will typically happen to bond prices?
0 Rise
o Fall (19.9\%)
o Stay the same
o No relationship
o I don't know

17. Which type of bond is the safest?
o U.S. Treasury bond $(\mathbf{7 6 . 3 \% )}$
o Municipal bond
o Corporate bond
o I don't know

18. Which of the following is the best definition for a "junk bond?"
o A bond that is rated as "below investment-grade" by rating agencies (39.6\%)
o A bond that has declined dramatically in value
$0 \quad$ A bond that has defaulted
o A bond that is not regulated
o I don't know

19. Which of the following best explains why many municipal bonds pay lower yields than other government bonds?
- Municipal bonds are lower risk
o There is a greater demand for municipal bonds
o Municipal bonds can be tax-free (18.5\%)
o I don't know

20. The principal difference between mutual fund share classes (Class A, Class B, Class C, etc.) is:
o The different investments each class makes
o The different fees and expenses each class charges $(16.1 \%)$
0 The different investment advisers in charge of managing each class
o I don't know

\section{Part 2 - Current Financial Planning Status, Financial Attitudes/Behaviors}

21. Overall, thinking of your assets, debts and savings, how satisfied are you with your current personal financial condition? Please use a 10-point scale, where 1 means "Not At All Satisfied" and 10 means "Extremely Satisfied." 
22. When thinking of your financial investments, how willing are you to take risks? Please use a 10-point scale, where 1 means "Not At All Willing" and 10 means "Very Willing."

23. Over the past year, how much did you spend in relation to your annual household income? Do not include unusual large purchases, such as the purchase of a new house or car, or other big investments you may have made. (multiple choice)
o Spent less than my annual household income
o Spent more than my annual household income
o Spent about the same as my annual household income
o Don't know

24. In a typical month, how difficult is it for you to cover your expenses and pay all your bills? (multiple choice)
o Very difficult
o Somewhat difficult
o Not at all difficult

25. Have you set aside emergency or rainy day funds that would cover your expenses for at least 3 months, in case of sickness, job loss, economic downturn, or other emergencies? (multiple choice)

$$
\begin{array}{ll}
\mathrm{o} & \mathrm{Yes} \\
\mathrm{O} & \mathrm{No}
\end{array}
$$

26. Do you currently have any dependent children? (multiple choice)

$$
\begin{array}{ll}
0 & \text { Yes } \\
0 & \text { No }
\end{array}
$$

27. (If yes) Do you currently have any money set aside for your children's college education? (multiple choice)

$$
\begin{array}{ll}
\text { o } & \text { Yes } \\
\text { o } & \text { No }
\end{array}
$$

28. Have you ever tried to figure out how much you need to save for retirement? (multiple choice)

$$
\begin{array}{ll}
0 & \text { Yes } \\
0 & \text { No }
\end{array}
$$

29. How confident are you that you could come up with $\$ 2,000$ if an unexpected need arose within the next month? (multiple choice)
o I am certain I could come up with the full $\$ 2,000$
o I could probably come up with $\$ 2,000$
o I could probably not come up with $\$ 2,000$
- I am certain I could not come up with $\$ 2,000$

30. In the past 12 months have you obtained a copy of your credit report? (multiple choice)

$$
\begin{array}{ll}
0 & \text { Yes } \\
\text { o } & \text { No }
\end{array}
$$

31. In the past 12 months have you checked your credit score? (multiple choice)

$$
\begin{array}{ll}
0 & \text { Yes } \\
\text { o } & \text { No }
\end{array}
$$

32. Have you attended any financial planning seminars since starting your residency and/or fellowship at Washington University/University of Arizona? (multiple choice)

o Yes

o No

33. In the last 5 years, have you asked for any advice from a financial professional about any of the following? (multiple choice) o Yes

- (If yes) Check all areas in which you have asked for advice

- Debt Counseling

- $\quad$ Savings or investments

- Taking out a mortgage or a loan

- Insurance of any type

- Tax planning

- $\quad$ Estate planning

- Asset protection

- How did you pay the financial professional for his/her advice? (multiple choice)

$$
\begin{array}{ll}
\text { o } & \text { Commission on products I purchase } \\
\text { o } & \text { Hourly fee regardless of type or quantity of advice } \\
\text { o } & \text { Yearly fee/retainer regardless of type or quantity of advice } \\
\text { o } & \text { Percentage of assets under management (AUM) } \\
\text { o } & \text { Combination of above } \\
\text { o } & \text { I received all of the advice for free } \\
\text { o } & \text { I don't know }
\end{array}
$$

o No

34. Do you currently have any student loans? Please include all undergraduate and graduate school debt. (multiple choice)

- Approximately how much in student loans do you currently owe? (drop down box)

- $\$ 0-24,999$

- $\$ 25,00-\$ 49,999$ 


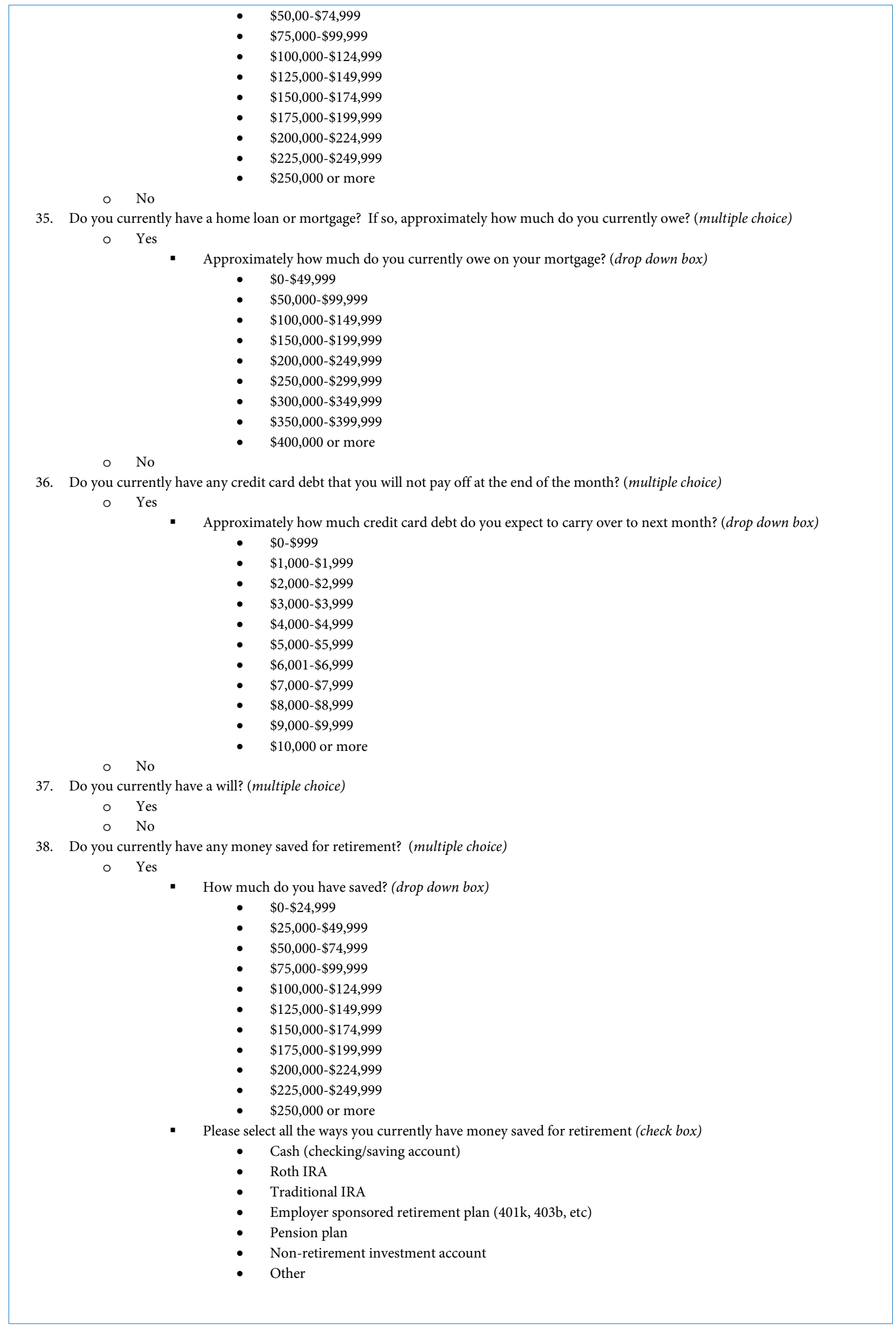


o No

39. After residency/fellowship training, do you plan to stay in an academic/university setting (e.g. WashU), private practice settings (outpatient or hospital based), or other settings? (drop down box)

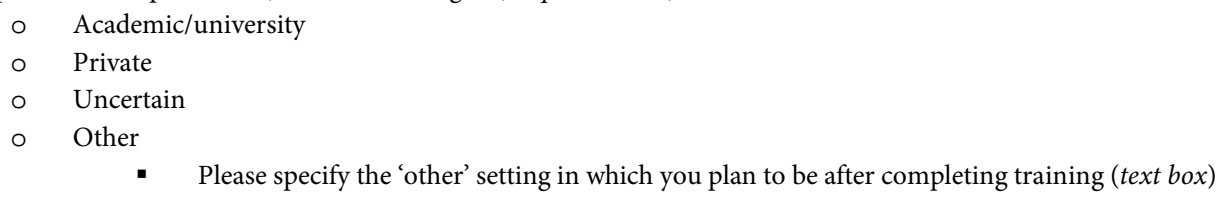

\section{Background/demographic questions}

40. Please enter your age in years ( 2 digit \#)

41. In what year did you graduate medical school (4 digit \#)

42. Please choose your postgraduate year of training (drop down box, PGY 1-10 or 11+)

43. What is your department/specialty? If you are completing a fellowship, select your specialty training program (e.g. if in adult cardiology, choose internal medicine. If in pediatric urology, choose surgery). (drop down box of all departments)

44. What is your marital status? (multiple choice)
o Married/Partner
o Single
o Separated
o Divorced
o Widow/widower

45. Please indicate the highest educational level attained by your mother (drop down box)
o Some High School Or Less
o High School Graduate
o Specialized Business Or Technical Training (Beyond High School)
o Some College (Incl. Associate Degree)
o Completed College (B.A., B.S.)
- Some Graduate Or Professional School (Required Beyond College)
o Master's degree (M.A., M.S., M.P.H., M.B.A., etc.)
o J.D.
o Ph.D., Ed.D. Sci.D., Or Equivalent
o D.D.S., D.V.M., D.P.M., Or Equivalent
o M.D., D.O., Or Equivalent
o M.D./Ph.D.
o M.D., D.O., Or Equivalent plus other advanced degree (not Ph.D.)
o I do not know

46. Please indicate the highest educational level attained by your father. (drop down box)

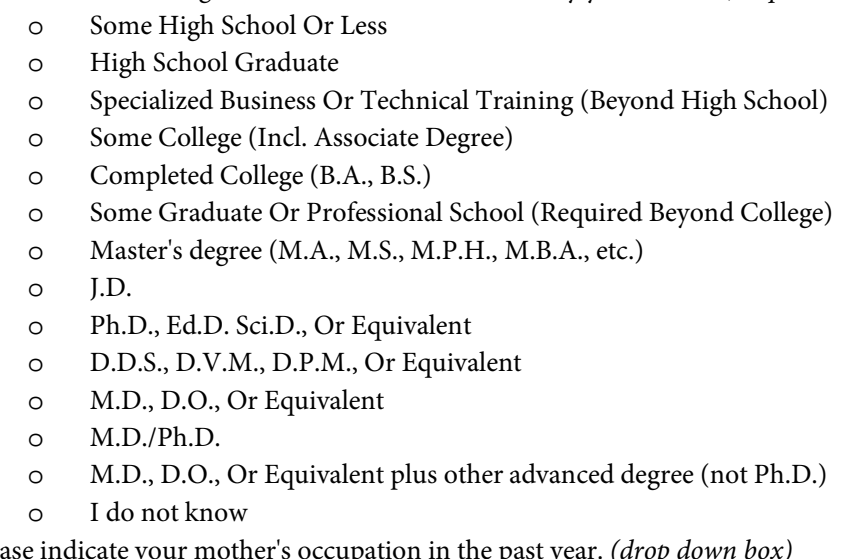

47. Please indicate your mother's occupation in the past year. (drop down box)
o Physician
o Dentist, Veterinarian, Optometrist, Podiatrist, Or Pharmacist
o Nurse
o Health Worker Other Than Above
- Lawyer Or Judge
o Mathematician Or Computer Scientist
o Natural Scientist 


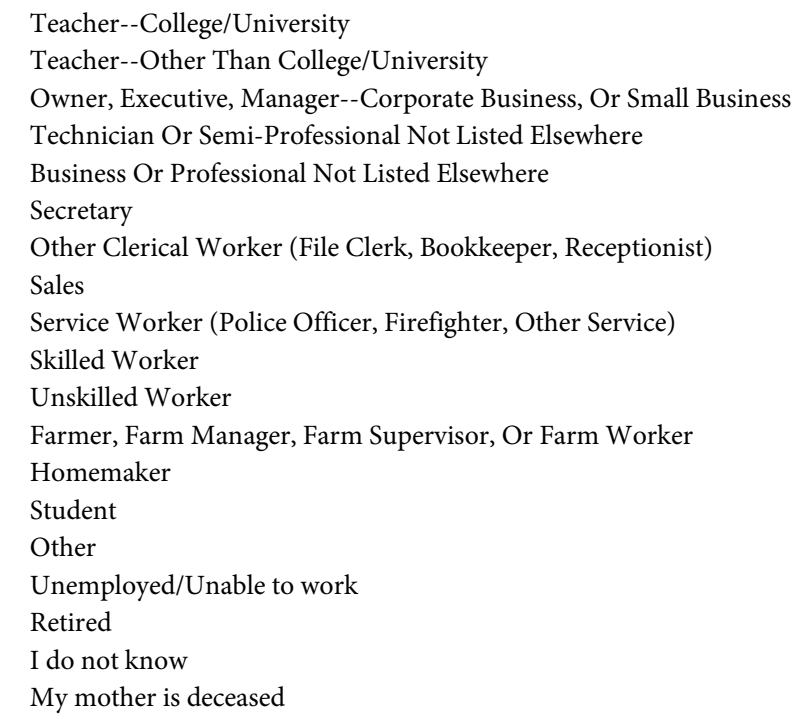

48. Please indicate your father's occupation in the past year. (drop down box)

$\begin{array}{ll}\text { o } & \text { Physician } \\ \text { o } & \text { Dentist, Veterinarian, Optometrist, Podiatrist, Or Pharmacist } \\ \text { o } & \text { Nurse } \\ \text { o } & \text { Health Worker Other Than Above } \\ \text { o } & \text { Lawyer Or Judge } \\ \text { o } & \text { Mathematician Or Computer Scientist } \\ \text { o } & \text { Natural Scientist } \\ \text { o } & \text { Teacher--College/University } \\ \text { o } & \text { Teacher--Other Than College/University } \\ \text { o } & \text { Owner, Executive, Manager--Corporate Business, Or Small Business } \\ \text { o } & \text { Technician Or Semi-Professional Not Listed Elsewhere } \\ \text { o } & \text { Business Or Professional Not Listed Elsewhere } \\ \text { o } & \text { Secretary } \\ \text { o } & \text { Other Clerical Worker (File Clerk, Bookkeeper, Receptionist) } \\ \text { o } & \text { Sales } \\ \text { o } & \text { Service Worker (Police Officer, Firefighter, Other Service) } \\ \text { o } & \text { Skilled Worker } \\ \text { o } & \text { Unskilled Worker } \\ \text { o } & \text { Farmer, Farm Manager, Farm Supervisor, Or Farm Worker } \\ \text { o } & \text { Homemaker } \\ \text { o } & \text { Student } \\ \text { o } & \text { Other } \\ \text { o } & \text { Unemployed/Unable to work } \\ \text { o } & \text { Retired } \\ \text { o } & \text { I do not know } \\ \text { o } & \text { My father is deceased }\end{array}$

